Continuity and Change: The Role of the HR Function in the Modern Public Sector 


\title{
Continuity and Change: The Role of the HR Function in the Modern Public Sector
}

\begin{abstract}
As the public sector has modernised and sought to become more efficient and cost-effective, the effective and strategic management of people has received increasing prominence and there have been calls for the $H R$ function to play a more strategic role. However, not much is known about whether the role of the HR function has changed substantively. In this paper, we present empirical evidence from six matched-pair public sector organisations in the UK to assess whether HR functional roles have changed, as envisaged, into a model more akin to the private sector. The findings highlight the complex and often contradictory nature of HR functional roles, and suggest that new and more strategic roles have not replaced traditional approaches but, rather, have been grafted on, giving rise to a variety of hybrid HR forms.
\end{abstract}




\section{Continuity and Change: The Role of the HR Function in the Modern Public Sector}

\section{Introduction}

The reform of structures, systems and processes within public services over the past 20 years has been well documented at an international level (Massey and Pyper, 2005; Boyne et al., 2004; Skalen, 2004; Harel and Tzafrir, 2002; Kessler et al., 2000; Bach and della Rocca, 2000; Barnett et al., 1996). The main purpose of these changes has been to increase the efficiency, cost-effectiveness and performance of public organisations, and has involved an increasing pressure from government on organisations to emulate private sector managerial practices, including performance management, customer orientation, and a heightened strategic focus (Boyne et al., 2004; Horton, 2003; Corby and Higham, 1996).

Since salaries can amount to up to $80 \%$ of organisational costs in the public sector, the domain of human resource management (HRM) has received renewed attention under these reforms (Horton, 2003; Barnett et al., 1996; Corby and Higham, 1996). Potentially, it has been argued, improved human resource management could facilitate the recruitment and retention of valued staff, enhance organisational costeffectiveness and serve to promulgate a performance-driven culture through the adoption of a more strategic HR role (Bach and della Rocca, 2000; Jaconelli and Sheffield, 2000; Ferlie et al., 1996).

However, despite the acknowledged significance of HRM under New Public Management (NPM), evidence as to whether or not there have been any substantive changes in the role of the HR function remains both partial and inconclusive (Selden, 2005; Lupton and Shaw, 2001; Boyne et al., 1999). This paper contributes to this important debate over the reality of change in the public sector, and seeks to answer the question: is there any evidence that the role of the HR function in the public sector has become more strategic?

First, we review the relevant literature, focusing particularly on the contested meaning and enactment of strategic HR roles within a public sector context. We then explain the methods used in our research study before presenting the findings from six case studies. In the discussion and conclusions, we highlight the complex 
and often contradictory nature of HRM approaches in the six organisations and argue that new, context-specific 'hybrid' HR roles are emerging.

\section{The Role of Human Resource Management in the Public Sector}

In the UK, up until the Conservative reforms which began in the 1980s, public administration was closely associated with the Weberian centralised, hierarchical model of public services, where administrative rules were determined by central government and implemented by public organisations with relatively little scope for strategising at a local level (Bach and della Rocca, 2000). Notions of paternalism, standardisation, job security, collectivism, developmental-humanism and the aspiration to be a 'model employer' were the values underpinning the management of people (Lupton and Shaw, 2001; Jaconelli and Sheffield, 2000; Boyne et al., 1999; Farnham and Horton, 1996).

Under NPM, this traditional approach came to be seen as something of a liability, undermining performance and demotivating individuals (Bach and della Rocca, 2000; Farnham and Horton, 1996). In a move mirrored by governments around the developed world (Selden, 2005), what were perceived as 'best practice' concepts of people management derived from the private sector were held up as ideals to which the public sector should aspire (Harris, 2004; Horton, 2003; Morgan and Allington, 2002; Kessler et al., 2000; Bach and della Rocca, 2000). Some of the core components of this imported model were performance-based rewards for staff, reducing the costs of employment, empowering organisations to take strategic decisions in the HRM field, increased flexibility in order to respond to customer demands, increased individualisation of the employment relationship, and decentralisation (Skalen, 2004; Horton, 2003; Farnham et al., 2003). Critical to this was the notion that HR functions could move away from their traditional administrative roles and become more strategically involved in their organisations than had hitherto been the case (Bach and della Rocca, 2000; Jaconelli and Sheffield, 2000).

However, this raises two important issues. First, what precisely is meant by a 'strategic' role for the HR function and, second, how can it be applied in a public sector context? 
The extensive conceptual literature on HR functional roles in the private sector has generally distinguished between roles that are largely concerned with administration, and those that are strategic in some way (Marchington and Wilkinson, 2005; Caldwell, 2003; Ulrich, 1998). Strategic roles have generally been viewed as focused on activities that will have long-term implications, such as the development of integrated HR strategies, involvement in organisational strategic decision-making, and managing organisational change. Administrative roles, on the other hand, are regarded as routine, reactive and tactical tasks associated with the operationalisation of HR policies, and employee-facing roles such as welfare and industrial relations (Marchington and Wilkinson, 2005; Boxall and Purcell, 2003; Caldwell, 2003; Truss et al., 2002; Ulrich, 1998).

The consensus within the prescriptive literature is that a move towards a more strategic role is desirable, if not essential, to the future of the HR function (Jamrog and Overholt, 2004; Ulrich and Beatty, 2001), whilst the conclusion within the empirical literature is that the role enacted by HR functions in most organisations in fact remains primarily administrative or reactive (Selden, 2005; Guest and King, 2004; Wright et al., 2004; Caldwell, 2003; Lawler and Mohrman, 2003; Truss et al., 2002).

The reality is that the $H R$ function in almost all organisations is required to play multiple and, often, conflicting roles, torn between the competing demands of employees, employers and professional norms (Caldwell, 2003; Legge, 1995; Kamoche, 1994). There is no evidence that one clear 'model' of strategic HR function roles exists within the private sector either conceptually or empirically that could be adopted by the public sector (Harris, 2004; Truss et al., 2002). Harris (2002) questions whether private sector HR roles can be held up as a model to which the public sector should aspire, even supposing one single model existed.

Substantial contextual differences have been highlighted between the public and private sectors that impact significantly on the role that the HR function may play. With a greater degree of openness to their environment, coupled with higher levels of public scrutiny and monitoring, public organisations have a much broader range of stakeholders than their private sector counterparts (Ring and Perry, 1985). These 
bring a multiplicity of objectives and priorities, compared with the more limited number of stable goals that exist for private sector firms (Harris, 2004; Klingner, 1993; Ring and Perry, 1985). This creates a complex and qualitatively different working environment for public managers, where top-down, strategic and linear planning processes, whether in general management or HRM, may be less appropriate than more incremental, emergent approaches that allow for adaptability and the ability to manage discontinuity (Harris, 2004; Ring and Perry, 1985).

Prior research has, in any event, been largely sceptical as to whether the processes of coercive isomorphism being imposed by governments on public sector HR functions will achieve the desired aim of shifting them towards a more strategic role (Harris, 2004; Bach, 1994; DiMaggio and Powell, 1983). The continuing dominance of central government imperatives over all public organisations through auditing and target-setting, combined with central control over resources, sets limits on managerial discretion and on the degree of strategic choice available to $H R$ actors within public organisations (Harel and Tzafrir, 2002; Harris et al., 2002; Bach and della Rocca, 2000; Kessler et al., 2000; Procter and Currie, 1999; Bach, 1994). As Chadwick and Cappelli (1999) argue, the degree of intentionality available to managers, in this case, HR managers, is critical.

Historically, the HR function in the public sector has lacked credibility and been regarded as peripheral and relatively powerless compared with other more powerful groups vying for resources (Horton, 2003; Lupton and Shaw, 2001; Corby and Higham, 1996). Resource dependence theory might suggest that unless HR functions can gain and maintain control over valued resources, then their position will be further weakened (Jackson and Schuler, 1995). However, Oswick and Grant (1996) go so far as to argue that ongoing public sector reforms are actually challenging the power of personnel specialists rather than strengthening it through a focus on cost control that reframes the HR function as an overhead to be cut.

Klingner (1993) reflects that HR's traditional role in the public sector of balancing the competing values of efficiency and responsiveness with individual rights and social equity is shifting towards a primary focus on cost and accountability under strategic HRM. However, it has also been argued that traditional public sector values continue to impact on the role and activities of the HR function, and that demonstrable 
fairness in the treatment of employees and the notion of the 'good employer' remain critical, alongside strategic pressures (Farnham et al., 2003; Harris, 2002; Boyne et al., 1999). The presence of these competing demands, set alongside the crosscutting stakeholder relationships and public accountability, creates a complex and contradictory setting in which HR functional roles are enacted.

Legacy factors, notably traditional approaches to managing the employment relationship, have been shown to be relatively enduring, exerting a strong counterpressure against an increasingly strategic role (Harris, 2004; Kessler et al., 2000). As Jackson and Schuler (1995) argue, HRM can be regarded as a sub-system embedded within a broader organisational system set in an institutionalised environment and subject to isomorphic pressures resistant to externally imposed change, mitigating against the uptake of new HRM approaches.

Within this context, empirical evidence over whether the role of the HR function can be considered 'strategic' is inconclusive. Whilst some studies suggest that public sector HR functions have not adopted a more strategic role (Teo and Crawford, 2005; Selden, 2005; Harris, 2004; Jaconelli and Sheffield, 2000; Boyne et al., 1999; Barnett et al., 1996), there is some counter-evidence that HR functions are adopting a more strategic role; for instance, Kelly and Gennard (1996) found that some NHS HR directors were involved in strategising, and Stock et al (1994) found evidence of a move towards the increasing professionalisation of the HR role.

However, given the centrality of the debate over HR roles to the whole new public management agenda, this is an area where more research is needed to find out in what ways the HR role is changing. Although Boyne et al. (1999) have conducted a large-scale quantitative survey of approaches to HRM in the public sector, this study does not analyse the role played by the HR department itself, so this area is ripe for further research. Set within the broader context of public management reforms, this paper seeks to contribute to the ongoing debate over whether or not HR functions are performing what can be considered a strategic role. Are public sector HR functions contributing merely at an administrative level, or is there evidence of an evolving strategic contribution? What role does the HR Director play in the senior decision-making fora, and what are the different perspectives of line and $H R$ managers on the role played by the department? 


\section{Methods}

In this study, we analyse the views of senior, line and HR managers in six, matchedpair public sector organisations in the UK with the aim of evaluating whether or not the role of the HR function can be described as 'strategic'. This is separate from, but clearly related to, issues surrounding the content of HR strategy itself. Building on Ulrich (1998) and Marchington and Wilkinson's (2005) distinction between strategic and administrative roles, we looked for evidence as to whether HR practitioners at a senior, mid and junior level were involved in long-term, strategic-level decisionmaking. In particular, we were concerned to find out whether HR's role in the organisation was proactive and involved, or just concerned with implementation and processing. Chadwick and Cappelli (1999: 5) underline the importance of 'intentionality' as a critical dimension of strategy, and we looked for evidence on freedom to act strategically to underpin the analysis.

Ring and Perry (1985) argue that strategic management in the public sector may require different behavioural responses compared with the private sector, and that pure, rational, top-down approaches may not be appropriate. We were therefore mindful of the need to explore the issue of what might be considered to be a strategic HR role from the perspective of the participants in the study. Given the lack of consensus in the literature as to whether or not HR can perform a strategic role in the public sector, and what, if any, that strategic role might look like, the study adopted an essentially exploratory approach, comparing and contrasting what were perceived as strategic versus administrative roles from the perspective of organisational actors. Evidence of a strategic role would potentially include the involvement of the HR director in key decision-making groups, structuring of the HR department with the explicit aim of partnering with line managers, involvement of mid-level HR managers in strategising at the business unit level, and evidence of efforts to develop long-term and organisationally integrated HR strategy and policies. Evidence of an administrative role would potentially include a focus on processing paperwork, providing information in response to requests, lack of involvement in key groups and lack of HR strategy, especially one linked in with organisational needs.

The case studies were: two borough councils, two police boroughs and two NHS acute trusts, all located in South-East England. We chose a matched-pair 
methodology, where organisations were matched according to size, task and location, in order to compare differences within the pairs, as well as across. This methodology was used effectively by Kessler et al (2000) to draw out differences and similarities across similarly constrained settings, and provides a means of establishing the extent to which organisational responses emerge due to a particular set of contingencies, or due to the exercise of strategic choice. The sample across the three organisation types was in part an opportunity sample of organisations willing to participate in the study, but was also chosen deliberately to represent three contrasting organisational settings.

Data were collected primarily by interview, with a total of 134 interviews held across the six case studies. Participants were senior and middle line managers, HR heads, directors and managers, trades union officials and, in the case of the borough councils, elected officials. In the police organisation, interviews were also held within the central HR function. Interviews were semi-structured, and lasted between 45 minutes and 1.5 hours. All were tape recorded and transcribed verbatim. Interviewees were asked their views on HR's main interventions in the organisation, what they were trying to achieve and why, and their views on HR's role. We asked whether the HR Head was on the main policy-making groups in the organisation, and what role they played in the process of strategic decision-making. We asked about the structure of the HR function and the extent to which HR managers worked with line and senior managers in developing unit-level strategies. Another area of focus was on the administrative role of the department, and we asked about the relative quantity of administrative work and what this work entailed. We were also interested in the terminology and underpinning values adopted by organisational actors, for example, checking for instances of the use of words like 'strategic' and the meaning ascribed to them.

The table below shows the numbers of interviews conducted at each level within each organisation:

INSERT TABLE 1 ABOUT HERE 
Case-study research has the advantage that in-depth data can be obtained that would not be possible in the case of a larger sample. A much more finely-grained understanding can therefore emerge of how HR's role is constructed through the lived experiences of organisational actors. Eisenhardt (1989: 68) argues that casestudy research has an important role to play in helping to understand the dynamics within single settings and can be used for theory building.

Basic background information is provided on each organisation in Table 2. The star rating assigned by the Audit Commission to the two councils and NHS Trusts are given, where three stars are awarded to the highest performing organisations, and no stars to the lowest. In the research design, it would have been preferable to have had a high and low performing organisation in each pair to maximise contrast (Eisenhardt, 1989); instead, we have a high and medium performer in the hospital and local council pairs. This is because the low performing organisations approached were unwilling to participate. Despite this limitation, it is felt that the participating organisations were sufficiently distinct to enable contrasts to be made. The police organisation is slightly different, in that two boroughs within the same district participated in the study. These two boroughs were effectively part of the same organisation and so we cannot compare them in the same way as they did not have similar levels of managerial discretion; despite this difference, we decided that the data from the police organisation were relevant and important to the study.

\section{INSERT TABLE 2 ABOUT HERE}

We report the data under two headings; first, we present evidence of any strategic roles played and, second, we discuss the contrasting administrative roles played by the HR function, before moving on to consider the implications for theory, practice and policy.

\section{Strategic HR Roles}

\section{Hospitals}

At Hospital A, the HR Director aspired to the HR department being seen as 'experts, specialists, problem-solvers, highly sensitised to the needs of line managers within 
the organisation'. He viewed his own role as 'strategic'. Clear HR objectives had been developed, linked in with the corporate objectives of the organisation. These had been discussed at both senior management and HR department levels, as evidenced in the following quotations: 'every year, we sit down as an Exec team and agree what our objectives would be for the coming year and there are always top HR objectives' (Senior line manager). Another senior line manager said: 'HR have a very good idea of what the Trust is tackling and their strategy is obviously geared to that'. An HR strategy document had been written by a multi-functional team, and these overall HR objectives were translated into individual objectives for $H R$ team members. The HR strategy was described as: 'responsive to the emerging needs of the organisation' (HR Director). The HR Director was on the main Trust board.

Generally, HR staff felt that they were able to play a much more proactive role than had previously been possible within the Trust, being actively involved in change projects and new initiatives: 'when I arrived here, it was very much a personnel function, more of an administrative function ... we then became a Trust and we realised we had to change, I've seen the department mature a lot ... we're almost there where it's more of an organisational development function' (HR Manager).

Although line managers were more negative about HR's contribution than HR staff themselves, the view that the role had changed over time was shared by them, notably the senior line managers. A typical comment was: 'it was pink and fluffy at one stage, it was indecisive, it was very much kind of more the welfare end of life, and it has moved much more in the direction of giving more focused advice and expertise' (Senior line manager). This more conservative view of HR's strategic role on the part of line managers as compared with HR managers reflects findings of other studies. Wright et al., (2001) suggest that where the disparity in perception is least, then this more often signifies lower expectations on the part of line managers than the fact that HR is, in fact, playing a more strategic role.

Hospital B'S HR function was headed by the HR and Facilities Director, who was a member of the Board with full voting rights. She had been with the Trust for many years, and was described by other senior managers as being a highly influential member of the senior management team: 'if she said, 'don't go down that route', we won't go down that route' (Chief Executive). 
The function as a whole was viewed by line and HR managers at all levels as being involved, proactive and strategic. There was a written HR strategy linked in with the strategic objectives of the Trust and cascaded down through the HR department through individual objectives. Whilst the organisation as a whole had an 'early mover' reputation in respect of bidding for grants, so did the HR function according to both line and HR managers: '[The Trust] has a reputation for doing things early or first ... and I think that's true for HR as well, so when we got to some meetings and are sharing information with other Trusts, you're not necessarily learning a lot ... we're ahead of other Trusts.' (HR Manager).

As was the case with Hospital A, Hospital B's HR interventions were circumscribed by national imperatives. However, there was evidence of a more proactive stance towards these than in Hospital A, and an awareness of areas where the hospital could exercise some discretion: 'there are some things that you are pretty much constrained by so you know you have to do them, and then there is some stuff that is local, options, and I think we're pretty good at looking at these things and taking a view that we want to manufacture an outcome that is positive for the organisation' (HR Manager). This was echoed by senior line managers and the HR Director, and stood in clear contrast with the views expressed in Hospital A.

A deliberate decision had been made to structure the function as a hybrid of centralised functions and teams devolved to business units, with the aim of maximising the involvement of HR in strategy at all levels: 'my personnel staff know what is going on because they go to the meetings, they are part of it' (HR Director). HR managers commented that they felt involved in the activities of the directorates to which they were attached, and line managers expressed the view that this structure enabled the HR managers to participate in decision-making, rather than merely provide administrative support.

\section{Councils}

At Council A, the HR function was represented at Board level by a director with overall responsibility for a range of support functions, and was led by an HR Head who had been in post for two years at the time of the study. As was the case with 
Hospital A, the perception was that the role of the HR function was in transition, with a shift towards being more strategic. Recently, an HR strategy and HR plan had been drafted, and an employee survey held, which had not been in place before. The prevailing view on the part of both $\mathrm{HR}$ and line managers was summed up by one HR manager, who said that HR had traditionally been seen as 'a bit of light relief between the important issues'. One problem the function faced was 'we've got so many policy gaps, real minimum standard stuff that we haven't got ... so we had a low credibility corporate HR function, it's improving' (HR Manager).

However, the feeling now was that HR had to demonstrate the added value they brought to the organisation: 'you've got to make sure that you've got a reason for being here' (HR Manager). These views were echoed by line managers, who mostly felt that HR's strategic involvement had been enhanced since the arrival of the incumbent HR Head. They cited as evidence in support of this view examples of new policies being developed that complemented the council's overall strategic direction, the increased visibility of the HR Head, and initiatives to align the HR activities of the various unit teams, which had previously been disconnected.

At Council B, the Chief Executive, who was previously the Council's HR Director, had very high expectations for the strategic role that the HR function would play at a senior level. The HR Head commented that 'ensuring our aims and objectives fit in with what the organisation needs and wants' was an important part of her role. Other line managers also viewed the HR function as involved in strategic work, but their understanding of what this meant encompassed activities such as the development and introduction of new policies, management development initiatives and on-line HR guides, which arguably operate at the policy, rather than the strategy level.

In a similar way to Hospital B, the council had gone beyond government guidelines in the new pay strategy they had recently introduced, and seen this as an opportunity to develop and enhance the overall HR strategy of the organisation.

The HR Head was described by one HR manager as 'very keen that we're at the leading edge' and to 'tap into best practice'. The CEO felt that to be a successful HR function it was imperative that 'you have an understanding of the business objectives 
and you have a distinctive contribution to make to those'. In this way, the linkage between HR strategy and corporate strategy appeared critical. The HR Head noted: 'we are very conscious of the strategic aims of the Council and we often have brainstorming exercises about how we contribute to them and what more we need to do'. This reflects an approach more normally associated with private sector 'best fit' approaches to HR strategy development (Gratton and Truss, 2003).

The prevailing view appeared to be, as was the case with the other organisations, that the HR role had developed through time. The HR Head said: 'it's grown from being more of a processing function to being much more strategic ... we've always really sought to become involved in ground-breaking work on new areas of development or leading edge policy'. This view was corroborated by line managers, especially senior line managers, who felt that the HR Head was heavily involved in strategic decisions around the overall direction of the council. There was a written HR strategy that was regularly reviewed and updated, linked in to the corporate objectives of the council. The CEO said: 'I can't conceive how you can be a high performing public sector organisation if you didn't have an HR function which was at the heart of what you were doing'. The terminology here was clearly one of competition, marketisation, performance, strategising and business focus. As was the case in Council $A$, one driver for the enhanced role of the HR function was the Government's council review process: 'if it was HR that lost them [three stars], it would mean the end of the world', said one HR manager.

\section{Police}

In the police authority, the central HR team was headed by an HR Director, who was a civilian and who reported to a senior police officer. There was a very large central HR function, responsible for policy and strategy development, but also for recruitment, induction, training and promotion of officers, and for monitoring the activities of the borough-level HR teams. The service had a central HR strategy, which was linked in with the overall priorities of the service.

HR had been devolved to borough level in the mid-1990s, with the aim of providing specialised HR advice to the local teams, and also of ensuring line managers took more responsibility for $\mathrm{HR}$ matters relating to their teams and to raise the strategic 
profile of HR by having a senior HR practitioner within each borough. Prior to this, HR had been dealt with at a local level by a Chief Inspector. The move in the mid1990s had been part of a wider set of initiatives to professionalise the function. One interviewee commented: 'there is a strong desire to be pitched at the cutting edge'. This was reflected in the large number of HR initiatives, one estimate was that there were 35 major HR initiatives currently under way, in addition to those where HR was a secondary consideration.

One of the main purposes of the HR function was to develop policies seen as 'equal, fair and politically correct' (line manager). The service was estimated by one central HR interviewee to have around $500 \mathrm{HR}$ policies with around 100 different staff grades. Cost-containment, meeting targets over workforce composition along diversity lines, and improving work-life balance issues were also critical targets imposed by the Home Office. As was the case with the other organisations, much of what might be considered strategic HR activity was driven by external imperatives.

As in Council A and Hospital A, there was a sense that HR's role was growing and becoming more strategic and involved over time. One interviewee from the central HR function said: 'I think the perception has improved over the last three years, I think we're definitely seen as being more involved with the business'. There was evidence that clear efforts were being made to inculcate the importance of $H R$ as a strategic issue in the line. For instance, performance related pay was in place for senior managers and failure to reach HR targets such as the number of individual performance development reviews submitted impacted directly on the Borough Commanders' performance related pay. The views expressed by line managers were generally more cautious. The HR function was perceived as a support function, rather than a strategically central concern, again reflecting the disparity in perspectives highlighted by Wright et al. (2001).

\section{Administrative HR Roles}

\section{Hospitals}

In Hospital A, there was evidence that administration continued to be important, as did the implementation of government initiatives such as Agenda for Change (the 
new NHS job grading and reward strategy) Improving Working Lives (the government's work-life balance initiative), and ensuring compliance with the European Working Time Directive. The HR Director commented: 'one frustrating thing about working in the NHS is that with such a huge agenda you feel that locally all you're doing is implementing the national agenda. The degree of flexibility and autonomy and local fit is squeezed into a very narrow opportunity locally. Agenda for Change isn't a choice'. This view was echoed by line managers. A typical comment was: 'I don't think they've got the opportunity to focus on much else [beyond the national agenda]'.

The HR Director felt the department was: 'vital in terms of running the routine in terms of recruitment extremely smoothly, providing expert advice ... helping and facilitating managers' (HR Director). The focus here is one of administration and processing, with HR providing an essential advisory role. Providing an efficient service, dealing with unions, and updating policies were also described by $H R$ managers as being central to HR's contribution. The majority of line managers did not regard HR as playing a strategic role: 'they understand the business of HR, but they're not always understanding of the business of the Trust' (line manager). HR was perceived to be reactive and, by some, to be actively obstructive, for instance through being too slow to process paperwork. Members of the HR function themselves felt that the line only contacted them in order to 'cover our backs', or viewed $H R$ as 'an overhead, welfare-oriented, always taking the side of staff' (HR Director). There was a disconnect between the aspirations of the HR director and the perceptions of other organisational actors, although the HR director himself clearly recognised this duality.

It was also clear that HR had not totally shed its industrial relations heritage. One line manager said: 'if we tried to invoke industry-type $H R$ policy and staff management within the NHS, we'd have $b^{* * * * y}$ anarchy on our hands. We are exceedingly tied by huge amounts of red tape around staff, including the involvement of all the staff side areas ... within the NHS, we're very protective of our staff' (line manager). Managing union relations was regarded as integral to the HR function's contribution. This suggests that HR's traditional collectivist role within the public sector was enduring, despite the introduction of more unitarist and strategic interventions. 
In Hospital B, although there was evidence that the strategic role of the function was stronger than at Hospital A, there was also evidence that the department continued to play an important administrative and advisory role. For instance, line managers saw HR's role as advisory, and expected them to provide workforce data and let them know of any HR changes that may impact on them. HR also had a significant and enduring welfare role to play, ensuring that staff were treated fairly and equitably, and also in dealing with the unions for instance to win their support for organisational change initiatives, as well as through the occupational health unit. The administrative underlay of the department persisted, providing back-up to the activities of the business-facing HR advisors. However, it is interesting that most line and senior managers in the organisation talked of HR's role in primarily strategic, rather than administrative terms.

\section{Councils}

As was the case in the NHS Trusts, the HR function at Council A was heavily influenced by government policy, for instance, a current focus was on bringing in single employment status for manual and office workers, although one HR manager said 'we're very late with it'. This reflects a perhaps more reactive approach compared with Hospital $B$ in response to government imperatives. Managing relations with unions was an important part of HR's role, although previously relations had been somewhat stagnant with draft policies being blocked by the unions. The new HR Head had driven through some policy changes despite union uncertainty. This was perceived positively by senior managers. The preferred approach now was to consult with the unions during the policy development process rather than waiting until later. There was a sense of union power having been depleted under the management of the new HR Head and of this being perceived positively by other organisational actors.

HR's strategic role in the council was felt to be adversely affected by the decentralised structure of the department. HR had been devolved during the mid1990s to unit level, leaving a small corporate HR group. These unit HR teams reported directly to the unit head, and had only a nominal relationship with the central HR team. Relations between the central and unit HR teams had become less 
positive over the years, with central HR viewed by some of them as 'obstructive and inflexible'. These structural problems impacted on the department's ability to implement centrally-developed HR strategies. The role played by the HR teams at unit level became increasingly administrative and supportive over the years.

Line managers' views on the HR function were predominantly negative, one described it as 'hopeless', although acknowledged that it had improved substantially under the new HR Head. One HR manager commented: 'there's a lot of stuff [being done now] that people have asked for', however, a lot of time was felt to be spent on fire-fighting and responding to problems. Despite the progress he felt had been made, the incumbent HR Head commented: 'I suspect a lot of it [HR activity] is reactive'.

At Council B there were clear expectations on the part of the HR function and line managers that HR had an important administrative role to play, such as in the area of recruitment, where 'if we don't get that offer out in writing to them within the next few days, $x$ borough will offer them a job and we'll lose them'. Thus, HR's contribution was viewed by both HR and line managers not just in terms of strategiclevel interventions, but also in terms of efficient administration. Line managers wanted the function to ensure paperwork was processed quickly and efficiently. Policy compliance, ensuring legal compliance, managing union relations and providing advice to line managers were also regarded as important aspects of HR's role by the line. Welfare issues continued to fall within HR's remit as well. Ensuring fairness, equality and equity, and work-life balance initiatives were regarded by the Chief Executive as integral aspects of the HR role, alongside HR strategy and organisational development.

\section{Police}

Within the police, it was evident that many line and HR managers felt that: 'HR remains very much a support function, which I think is appropriate' (HR manager, central HR). There was a sense that HR strategy was, as one interviewee described it, 'in that secondary pot' as a support to the main strategic requirements of the organisation. The tight regulatory framework surrounding police officers' status as 
Crown appointees was felt to circumscribe HR's role; one interviewee summed up the general view by saying: 'it's actually quite hard to be innovative'.

Although the idea originally had been that the borough-level HR managers would provide strategic advice and consultation to the line managers, in practice, a large administrative burden had fallen upon their shoulders. Compliance with central edicts, collating and reporting back on workforce data and processing paperwork formed a large part of the job performed by the local HR units. This was summed up by one interviewee from central HR who commented: 'there should be an HR manager who provides a strategic and interventionist support for the Borough Commanders for dealing with people management things, but they still tend to be heavily involved in the transactional stuff'.

At both boroughs, the two HR Managers were members of the senior management team. This senior management role should, in theory, have provided scope for the HR managers to develop a strategic and proactive role. This was partially true in one borough, where a local HR plan had been developed that linked in with the overall service HR strategy, and outlined objectives for the local HR unit. In the other unit, in contrast, no HR plan had been developed, although some line managers had been pressing for one. The feeling was that HR's strategic involvement at a local level was circumscribed by the centre: 'an awful lot is centrally driven' (senior line manager).

Both HR units were felt to be under a great deal of pressure due to the quantity of administrative work. Many of the staff were also unqualified, and therefore were largely performing a clerical role. One line manager said: 'all they do is facilitate the flow of paperwork'. This meant that a great deal of pressure was placed upon the HR Manager of the borough and the unit: 'my feeling with the HR department here at the moment is there are too few staff and too much work' (Line manager). Outdated systems and processes were felt to inhibit HR from playing a more strategic role: 'a police officer changes their address; there are currently four people involved inputting that address into the system and managing that address change'. Another major role at borough level was staff welfare, both dealing with staff who had been injured on duty or were ill, as well as processing the relevant paperwork. 
Nevertheless, it was apparent that the HR managers at both boroughs were held in high regard by both officers and other civilian staff. One, in particular, was described as: 'very, very respected', although her workload was felt to be 'totally unrealistic'. One senior line manager said: 'I think the HR manager would say she would love to be doing more [strategic HR] if she could raise herself out of the mire of dealing with all the other things'.

Symbolically, and through employment contracts, the HR function was regarded as separate from the line of the organisation. Many policies were regarded by police officers 'as a nuisance' and the imposition of targets such as individual performance development review (PDR) returns was seen as detracting from policing work particularly since, as the HR manager noted, 'it's very disjointed' so, for instance, PDRs were a requirement, but were not actually used for any purpose. Some line managers saw HR as 'cumbersome, bureaucratic', 'a hindrance', 'reactive'. There was also evidence that HR's role in the organisation was adversely affected by the sub-cultural divide between police officers and police staff.

However, some viewed HR's role as having been transformed in recent years: 'their role is getting bigger by the day' (Senior line manager). Many line managers wanted $\mathrm{HR}$ to provide advice and process information in a timely fashion, but felt that the department was unable to deliver this due to pressures caused by the administrative workload.

\section{Discussion}

The findings from this study provide a fascinating and detailed insight into the role of the HR function in the public sector under the Blair administration. First, it is evident that we are witnessing an ongoing evolution. In all organisations, we heard evidence that the role of the HR function had changed over time, and substantially so over the past 10 years. Generally, the view was that these changes were positive, and that HR's role had grown in complexity and contribution. In all organisations, we heard clear examples of the way in which HR's role had become increasingly strategic, proactive and interventionist, and, generally, both line managers and HR managers welcomed these changes. This development reflects the expected trend towards an increasingly strategic HR role under the public sector reform agenda, and 
provides a counterbalance to the more pessimistic findings of earlier studies such as that of Kessler et al. (2000).

However, it is clear that these changes have not replaced the 'traditional' public sector HR approach, rather, they had been grafted on to existing HR functional roles. As Harris (2004) has argued, public sector HR managers have to balance multiple and, often, conflicting roles as they seek to satisfy the needs of a broad range of stakeholders and professional norms. The strategic imperative has created another role which the function is called upon to adopt. There is no evidence from our study that this has been accompanied by extra resources; indeed, in all organisations but especially Hospital A, resources have been cut.

Dealing with union relations remained a critical element of the HR role, evidence that the pluralist underpinnings of the public sector HRM remain intact, although all organisations noted that relations with the unions were good. Morgan and Allington (2002: 38) reported that public sector trade union density has fallen in recent years, and so it could be conjectured that this aspect of the HR role may also decline in importance over time.

All the HR functions performed reactive, administrative and processing roles, alongside the newer, more strategic, interventionist and proactive roles. To this can be added the ongoing importance of HR's welfare role, which was particularly pronounced in the police, but evident in all the organisations. Although Ulrich (1998) has argued that HR functions need to assume multiple roles in order to contribute, it was clear from the study that this created tensions in terms of time constraints, role ambiguity and conflicting expectations. These tensions are by no means confined to the public sector, as Wright et al.'s (2001) study shows, HR functions generally are called upon to play multiple roles. What appears true from this study and other research within the public sector is that the particularities of public administration mean that the tensions and ambiguities experienced by public personnel officers are more complex than those in the private sector. The addition of a strategic role into the mix, whilst creating new opportunities, also serves to heighten these tensions.

In view of the data we have collected, it would be misleading to talk of a totally new model of HR roles within the public sector. Rather, we have a range of hybrid 
models that, at times, create tension and contradiction for the HR function (Harris, 2004). This challenges the argument of Boyne et al (1999) that a dominant public service ethos mitigates against the uptake of private sector practices; rather, our findings suggest that such practices are being adopted, as well as adapted, alongside the more traditional roles.

The drive for change appeared to be coming from a number of sources. One major factor was government's approach to evaluating the performance of public sector organisations. For instance, in the case of the councils, it was very clear that the presence of a strategic HR function played a critical role in the overall performance evaluation of the organisation (Massey and Pyper, 2005). Consequently, HR functions were subject to coercive pressure to change (Paauwe and Boselie, 2003). All the HR heads participating in the study expressed the personal wish to develop the function in a more strategic direction. This reflects normative pressures being exerted on the HR functions (Paause and Boselie, 2003). Of course, this may be peculiar to the particular sample of organisations involved, and so a broader study that investigated this across a wider sample of organisations would be welcome. The third source of pressure came from senior and line managers within the organisations, and there was clearly a desire on their part to see HR becoming more proactive in terms of their contribution. These three sources of pressure were closely interlinked. Conversely, there was clearly some ambiguity in terms of what was considered a 'desirable' role for HR, and this was particularly apparent in the police, where cultural norms dictated the pre-eminence of police officers and policing matters over civilian staff and management.

We can also observe interesting differences within and across the three sectors that have been the focus of this study. In the case of the hospital trusts, it was evident that different levels of strategic integration had been reached, with Hospital B'S HR function playing more of a strategic role than that within Hospital A. In Hospital B, it appeared that the capability of the HR function to become involved strategically at all levels was much more developed than in Hospital A. Similarly, Council A's HR function was further behind that of Council B in terms of its strategic involvement, although in both cases it was clear that the incumbent HR director had brought a significantly increased strategic focus to $H R$ departmental activities. It was therefore apparent that the degree of shift was not sector-specific, but depended 
heavily on the actions and intentions of organisational actors, particularly the HR Director or Head, as well as the prevailing organisational context. The findings from the two local councils present a different view from those of Harris (2004), who found that the possibilities for innovation within local councils' HR functions were limited, and also counter those of Kessler et al (2000). However, the findings support those of Truss et al. (2002), who argue that a range of factors influences the role played by the HR function, one of them being the actions and aspirations of the senior HR manager, and another the attitude of the Chief Executive towards the HR function.

In all organisations, it was clear that implementing initiatives from a central source, such as the Home Office in the case of the police, the Office of the Deputy Prime Minister in the case of the councils, and the central NHS in the case of the Trusts, was a main concern for all HR functions, and served to circumscribe their degree of strategic choice. This reflects the findings of earlier studies (Kessler et al., 2000; Truss, 2003). However, within these imposed frameworks, it was also clear that there was considerable scope for innovation at a local level. This had been most developed in Hospital B and Council B, where there was evidence that senior HR Managers had deliberately acted to meld central imperatives with local-level concerns into a considered local HR strategy that aimed to meet the needs of both the centre and the local organisation. This counters the earlier findings of Bach (1994), later supported by Lupton and Shaw (2001), who argued that the potential for HR functions within the NHS to be strategic was limited by central edict. Hospital A and Council A were also in the throes of explicitly repositioning themselves to pursue the same path, but because they had started later than the other two organisations, were further behind. Nevertheless, a similar trajectory was being followed.

We also need to take into account the generally more negative views of line vs HR managers over the extent to which HR was playing a strategic role. Based on Wright et al.'s (2001) data, this gap exists in the private as well as the public sector. They argue that the gap may be narrowed through internal marketing efforts and through HR functions developing quantitative metrics to illustrate how they are making a strategic contribution. Certainly, in our study, the gap in perceptions was least in Hospital B and Council B, where the Chief Executive's expectations of HR's strategic roles were high, bolstered by a long organisational history of successful strategic HR 
involvement. This suggests that there is much that can be done within public sector organisations to enhance HR's strategic role.

The study has also brought to light the complex and multifaceted nature of HRM in the modern public sector. Whilst much of the literature to date had discussed 'traditional' and 'new' public sector HRM as polar opposites, what emerges from this in-depth study is that HR departments perform both of these roles at different times, and in different areas of activity. For instance, paperwork and processing data continued to be an integral part of what the HR functions did in all organisations. This element of work could not be described as strategic; however, other areas of activity, such as developing an HR strategy, inputting into the organisational strategy and workforce planning clearly were strategic activities. Whilst some aspects of the role were clearly collectivist, in terms of relations with the union and ensuring standardisation of employment contracts, other areas, such as introducing performance related pay, were unitarist. Our data therefore show that HRM in the public sector has moved on from the stereotypical 'traditional' public sector model, but has not evolved into the exclusively unitarist and managerialist human resource management role envisaged by some. This creates an interesting and complex role for the HR function at the nexus between professional imperatives, government agendas, the demands of senior and line managers and their own will to change the nature of their contribution (Harris, 2004; Truss et al., 2002).

\section{Conclusions}

This study has explored the question of whether the role of the HR function has become more strategic under the reform agenda. Through analysing in-depth data from six case study organisations, our conclusion is that $H R$ is in a continuous cycle of change and evolution. There is clear evidence that the HR role is becoming increasingly strategic, but this role is not replacing traditional HR roles, rather, it is being grafted on, adding to the diversity, challenge and complexity of $H R$ in the public sector. Our findings show that change within public sector HRM has progressed much further than earlier research would suggest. From a policy perspective, it is clear that the government's change agenda is taking effect. However, there is also evidence that in some organisations, such as the police, the full potential of the function is being held back by cumbersome and time-consuming 
procedures. There is therefore a need to investigate new ways of streamlining and reducing the burden of process, as well as investigating in more detail how tensions and conflicts within the role can be addressed.

Of course, this study has some limitations. First, the sample is small, and so there is a limit to the generalisability of the findings, although the aim of the study was to gain a multi-faceted and detailed understanding of the implementation of HRM in specific public sector organisations. A large-scale study that examined the propositions developed at a quantitative level would be welcome. Second, not all kinds of organisation within the public sector were included, and it would be interesting to see the impact of change on the large, civil service HR departments, and other organisations at the cusp between public and private sectors.

\section{Acknowledgement}

I would like to thank Jas Gill for his help in collecting the data upon which this paper is based. 


\section{REFERENCES}

Bach, S. 1994. 'Restructuring the Personnel Function: the Case of NHS Trusts'. Human Resource Management Journal, 5, 2, 99-115.

Bach, S. and Della Rocca, G. 2000. 'The Management Strategies of Public Service Employers in Europe'. Industrial Relations Journal, 31, 2, 82-96.

Barnett, S., Buchanan, D., Patrickson, M. and Maddern, J. 1996. 'Negotiating the Evolution of the HR Function: Practical Advice from the Health Care Sector'. Human Resource Management Journal, 6, 4, 18-37.

Boxall, P. and Purcell, J. 2003. Strategy and Human Resource Management. Basingstoke: MacMillan.

Boyne, G. 2002 'Public and Private Management: What's the Difference?' Lournal of Management Studies, 39, 1, 97-122

Boyne, G., Jenkins, G., and Poole, M. 1999. 'Human Resource Management in the Public and Private Sectors: An Empirical Comparison'. Public Administration, 77, 2, 407-420.

Boyne, G, Martin, S. and Walker, R. 2004. 'Explicit Reforms, Implicit Theories and Public Service Improvement'. Public Management Review, 6, 2, 189-210.

Caldwell, R. 2003. 'The Changing Roles of Personnel Managers: Old Ambiguities, New Uncertainties'. Lournal of Management Studies, 40, 4, 983-1004.

Chadwick, C. and Cappelli, P. 1999. 'Alternatives to Generic Strategy Typologies in Strategic Human Resource Management'. Research in Personnel and Human Resources Management, Supplement 4, 1-29.

Corby, S. and Higham, D. 1996. 'Decentralisation of Pay in the NHS: Diagnosis and Prognosis'. Human Resource Management Journal, 6, 1, 49-65. 
DiMaggio, P. and Powell, W. 1983. 'The Iron Cage Revisited: Institutional Isomorphism and Collective Rationality in Organizational Fields'. American Sociological Review, 48, 147-160.

Eisenhardt, K. 1989. 'Building Theories from Case Study Research'. Academy of Management Review, 14, 532-550.

Farnham, D. and Horton, S. 1996. 'Managing public and private organisations', in Farnham, D. and Horton, S. (eds) Managing the New Public Services. London: Macmillan.

Farnham, D., Horton, S. and White, G. 2003. 'Organisational Change and Staff Participation and Involvement in Britain's Public Services'. International Journal of Public Sector Management, 16, 6, 434-445.

Ferlie, E, Ashburner, C., Fitzgerald, L. And Pettigrew, A. 1996. The New Public Management in Action. Oxford: Oxford University Press.

Gratton, L. and Truss, C. 2003. 'The Three-Dimensional People Strategy: Putting Human Resources Policies into Action'. Academy of Management Executive, 17, 3, 74-86.

Guest, D. and King. Z. 2004. 'Power, Innovation and Problem-Solving: The Personnel Manager's Three Steps to Heaven'. Lournal of Management Studies, 41, 3, 401-23.

Harel, G. and Tzafrir, S. 2001. 'HRM Practices in the Public and Private Sectors: Differences and Similarities'. Public Administration Quarterly, Fall, 316-355.

Harris, L. 2002. 'The Future for the HRM Function in Local Government: Everything has Changed - but has Anything Changed?' Strategic Change, 11, 7, 369-378.

Harris, L. 2004. UK Public Sector Reform and the 'Performance Agenda' in UK Local Government - HRM Challenges and Dilemmas. Paper to the HRM and Performance Conference, Bath University, April. 
Harris, L., Doughty, D. and Kirk, S. 2002. 'The Devolution of HR Responsibilities: Perspectives from the UK's Public Sector'. Lournal of European Industrial Training. $26,5,218-230$.

Horton, S. 2003. 'Participation and Involvement: The Democratisation of New Public Management'. International J ournal of Public Sector Management, 16, 6, 403-411.

Jackson, S. and Schuler, R. 1995. 'Understanding Human Resource Management in the Context of Organizations and their Environments'. Annual Review of Psychology, 46, 237-264.

Jaconelli, A. and Sheffield, J. 2000. 'Best Value: Changing Roles and Activities for Human Resource Managers in Scottish Local Government'. International Journal of Public Sector Management, 13, 7, 624-644.

Jamrog, J. and Overholt, M. 2004. 'Building a Strategic HR Function: Continuing the Evolution'. Human Resource Planning, 27, 1, 51-62.

Kamoche, K. 1994. 'A Critique and Proposed Reformulation of Strategic Human Resource Management'. Human Resource Management Journal, 4, 4, 29-43.

Kessler, I., Purcell, J. and Coyle Shapiro, J. 2000. 'New Forms of Employment Relations in the Public Services: The Limits of Strategic Choice'. Industrial Relations Lournal, 31, 1, 17-34.

Klingner, D. 1993. 'Reinventing Public Personnel Administration as Strategic Human Resource Management'. Public Personnel Management, 22, 4, 565-578.

Lawler, E. and Mohrman, S. 2003. 'HR as Strategic Partner: What does it take to make it happen?' Human Resource Planning, 26, 3, 15-30.

Legge, K. 1995. Human resource management: Rhetorics and realities. Basingstoke: MacMillan. 
Lupton, B. and Shaw, S. 2001. 'Are Public Sector Personnel Managers the Profession's Poor Relations?' Human Resource Management Journal, 11, 3, 23-38.

Marchington, M. and Wilkinson, A. 2005. Human resource management at work. CIPD: London.

Massey, A. and Pyper, R. 2005. Public Management and Modernisation in Britain. Basingstoke: Palgrave MacMillan.

Morgan, P. and Allington, N. 2002. 'Has the Public Sector Retained its Model Employer Status?'. Public Money and Management Jan-Mar, 35-42.

Nutley, S. 2000. 'Beyond Systems: HRM Audits in the Public Sector'. Human Resource Management Journal, 10, 2, 21-38.

Oswick, C. and Grant, D. 1996. 'Personnel Management in the Public Sector'. Personnel Review, 25, 2, 4-18.

Paauwe, J. and Boselie, P. 2003. 'Challenging Strategic HRM and the Relevance of the Institutional Setting'. Human Resource Management Journal, 13, 3, 56-70.

Procter, S. and Currie, G. 1999. 'The Role of the Personnel Function: Roles, Perceptions and Processes in an NHS Trust'. International Journal of Human Resource Management, 10, 6, 1077-1091.

Pfeffer, J. 1998. The Human Equation: Building Profits by Putting People First. Boston: Harvard Business School Press.

Ring, P. and Perry, J. 1985. 'Strategic Management in Public and Private Organizations: Implications of Distinctive Contexts and Constraints'. Academy of Management Review, 10, 2, 276-286.

Selden, S. 2005. 'Human Resource Management in American Counties, 2002'. Public Personnel Management, 34, 1, 59-84. 
Skalen, P. 2004. 'New Public Management Reform and the Construction of Organizational I dentities'. International J ournal of Public Sector Management, 17, 3, 251-263.

Teo, S. and Crawford, J. 2005. Indicators of Strategic HRM Effectiveness: A Case Study of an Australian Public Sector Agency During Commercialization'. Public Personnel Management, 34, 1, 1-16.

Truss, C. 2001. 'Complexities and Controversies in Linking Human Resource Management and Organisational Performance'. Lournal of Management Studies, 38, 8, 1121-1150.

Truss, C. 2003. 'Strategic HRM: Enablers and Constraints in the NHS'. International Lournal of Public Sector Management. 16, 1, 48-60.

Truss, C., Gratton, L., Hope-Hailey, V. and Stiles, P. 1997. 'Soft and hard models of Human Resource Management: A Reappraisal'. Lournal of Management Studies, 34, 1, 53-73.

Truss, C., Gratton, L., Hope-Hailey, V., Stiles, P. and Zaleska, J. 2002. 'Paying the Piper: Choice and Constraint in Changing HR Functional Roles'. Human Resource Management Journal. 12, 2, 39-63.

Ulrich, D. 1998. 'A New Mandate for Human Resources'. Harvard Business Review, $76,1,124-134$.

Ulrich, D. and Beatty, D. 2001. 'From Partners to Players: Extending the HR Playing Field'. Human Resource Management, 40, 4, 293-307.

Wright, P., S. Snell and P. Jacobsen. 2004. 'Current Approaches to HR Strategies: Inside-Out versus Outside-In'. Human Resource Planning, 27, 36-47.

Wright, P., McMahan, G., Snell, S. and Gerhart, B. 2001. 'Comparing Line and HR Executives' Perceptions of HR Effectiveness: Services, Roles and Contributions'. Human Resource Management, 40, 2, 111-123. 


\begin{tabular}{|l|c|c|}
\hline Organization & Line I nterviews & HR I nterviews \\
\hline Council A & 14 (incl 2 Councillors) & 10 \\
\hline Council B & 10 (incl 2 Councillors) & 6 \\
\hline Hospital A & 10 & 5 \\
\hline Hospital B & 12 & 3 \\
\hline Police Borough A & 18 & 3 \\
\hline Police Borough B & 24 & 7 \\
\hline Central Police & 2 & \\
\hline
\end{tabular}

Table 1: Number of I nterviews Conducted

\begin{tabular}{|c|c|c|c|c|c|c|}
\hline & Council A & Council B & Hospital A & Hospital B & Police A & Police B \\
\hline $\begin{array}{l}\text { Type of } \\
\text { Organization }\end{array}$ & $\begin{array}{l}\text { Borough } \\
\text { Council }\end{array}$ & $\begin{array}{l}\text { Borough } \\
\text { Council }\end{array}$ & Acute Hospital & $\begin{array}{l}\text { Acute } \\
\text { Hospital }\end{array}$ & $\begin{array}{l}\text { Police } \\
\text { Borough }\end{array}$ & Police Borough \\
\hline $\begin{array}{l}\text { No. of em- } \\
\text { ployees }\end{array}$ & 2,500 & 2,100 & 2,500 & 3,000 & 650 & 900 \\
\hline Star Rating & 2 star: ‘Good' & $\begin{array}{l}3 \text { star: } \\
\text { 'Excellent' }\end{array}$ & 2 star: 'Good' & $\begin{array}{l}3 \text { star: } \\
\text { 'Excellent' }\end{array}$ & $\mathrm{n} / \mathrm{a}$ & $\mathrm{n} / \mathrm{a}$ \\
\hline Comment & $\begin{array}{l}\text { Perceived by } \\
\text { respondents } \\
\text { as high } \\
\text { performing } \\
\text { council with } \\
\text { some key } \\
\text { units } \\
\text { underper- } \\
\text { forming }\end{array}$ & $\begin{array}{l}\text { High } \\
\text { performing } \\
\text { council }\end{array}$ & $\begin{array}{l}\text { Ongoing } \\
\text { history of } \\
\text { financial } \\
\text { difficulties; } \\
\text { one of last to } \\
\text { convert to } \\
\text { Trust' status }\end{array}$ & $\begin{array}{l}\text { Consistently } \\
\text { high } \\
\text { performing } \\
\text { hospital, } \\
\text { converted to } \\
\text { elite } \\
\text { 'Foundation' } \\
\text { status shortly } \\
\text { after research }\end{array}$ & $\begin{array}{l}\text { Two police } \\
\text { boroughs part } \\
\text { of larger } \\
\text { police } \\
\text { authority and } \\
\text { therefore had } \\
\text { the same } \\
\text { senior } \\
\text { management; }\end{array}$ & $\begin{array}{l}\text { they are } \\
\text { therefore not } \\
\text { independent } \\
\text { organisations as } \\
\text { are the other } \\
\text { two pairs. }\end{array}$ \\
\hline
\end{tabular}

Table 2: Background Organisational Data 